\title{
John Wesley Powell's Exploration of the Colorado River
}

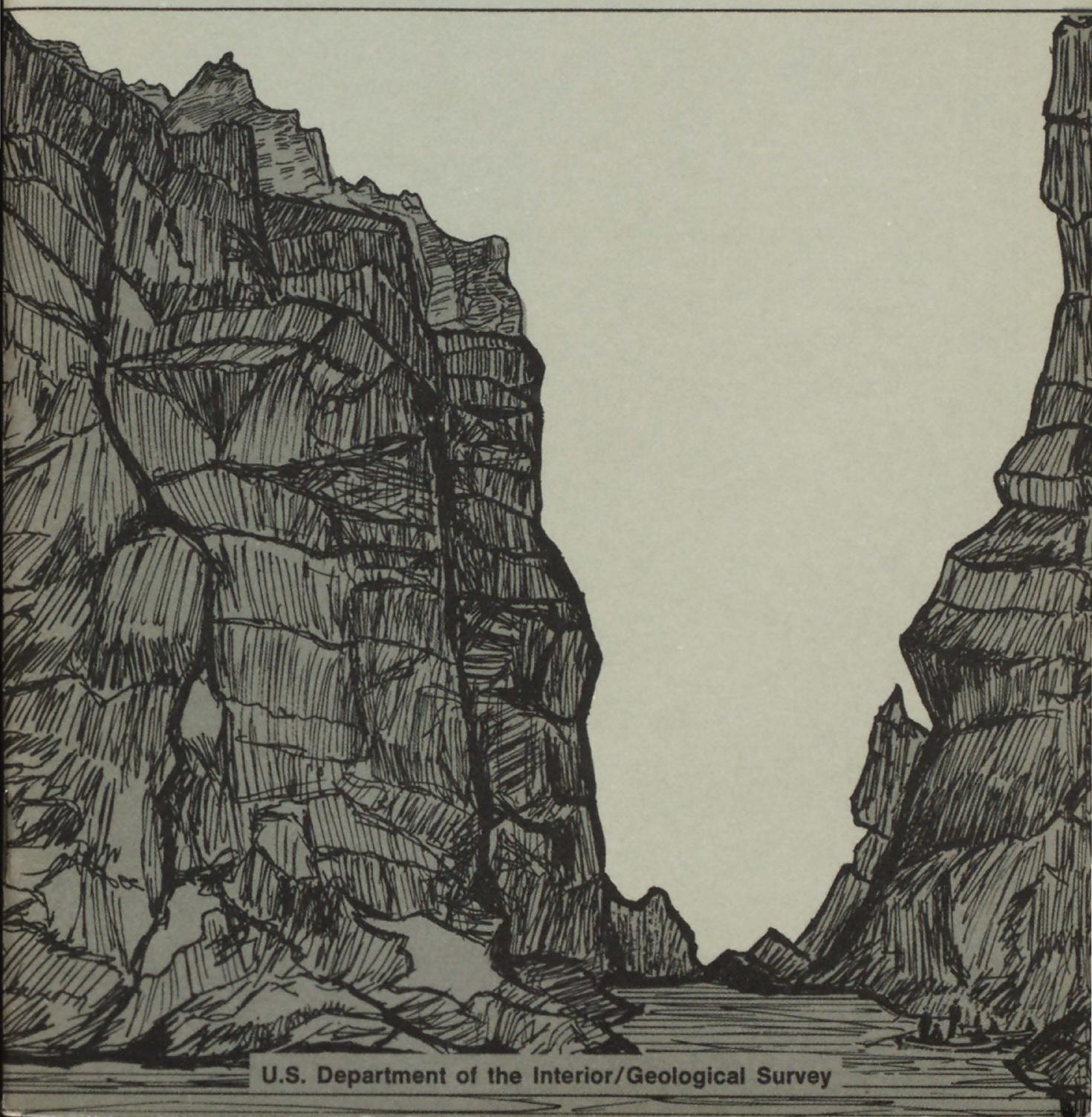




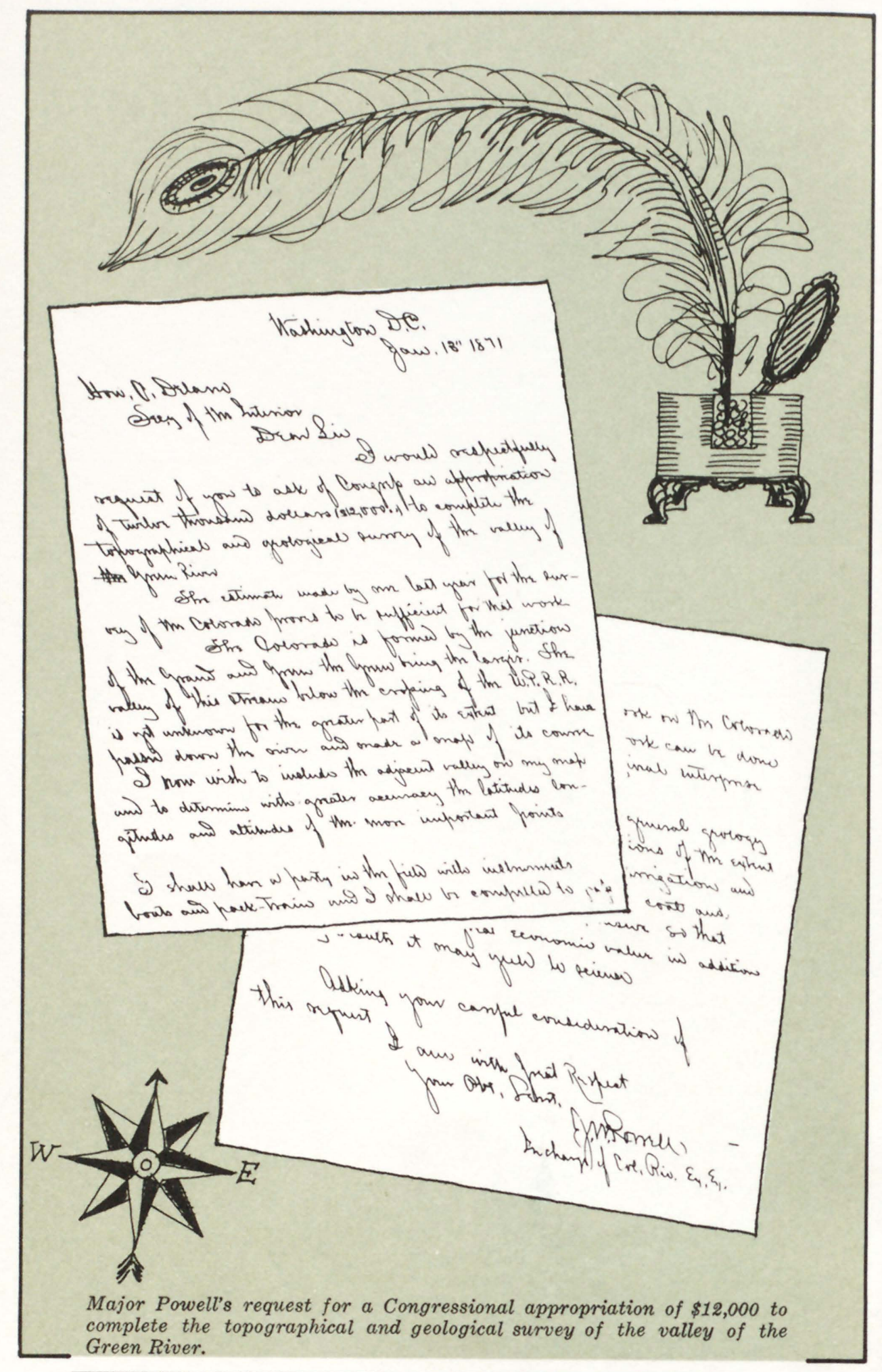

\section{JOHN WESLEY POWELL'S \\ EXPLORATION of the COLORADO RIVER}

by Mary C. Rabbitt

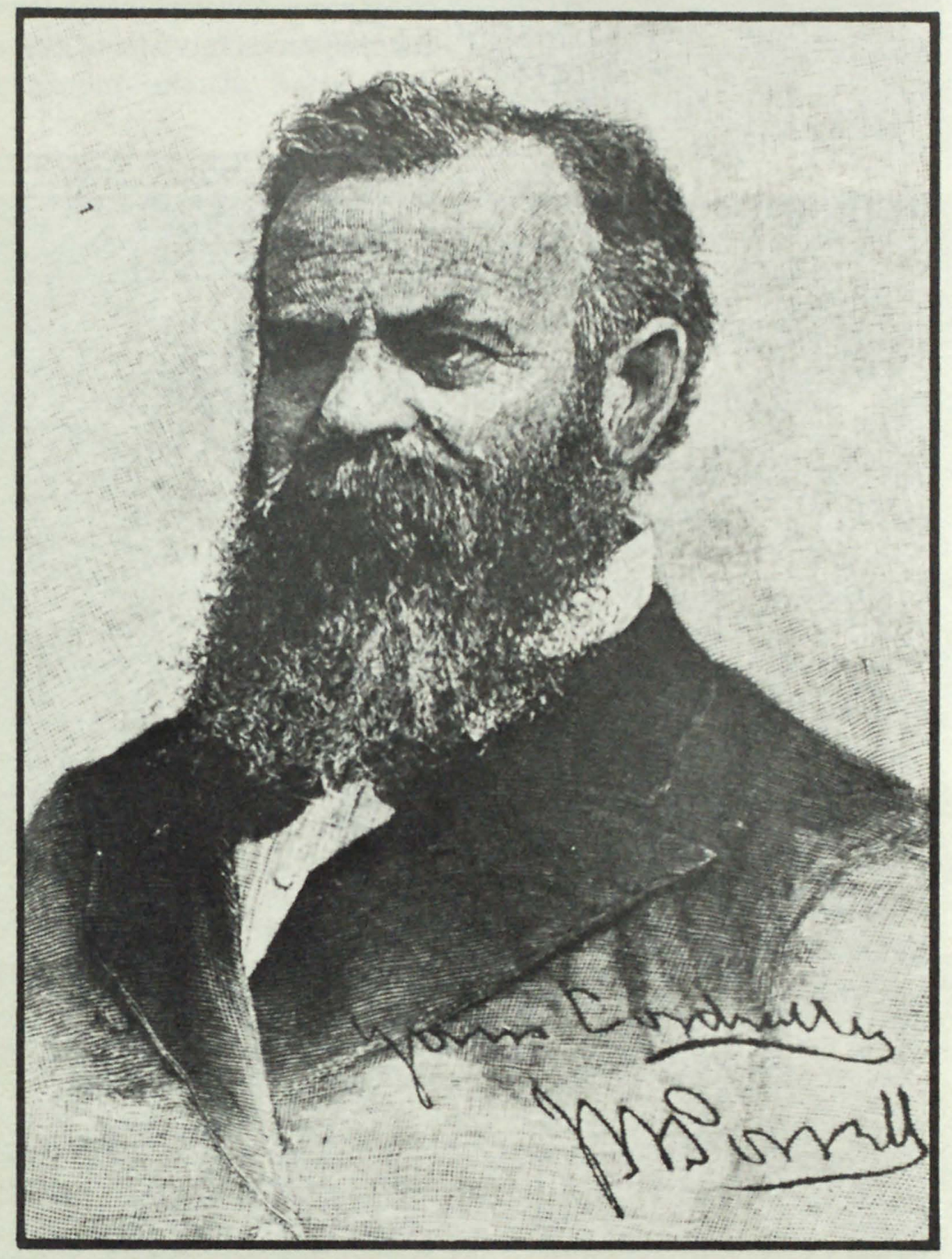

For sale by the Superintendent of Documents, U.S. Government Printing Office 


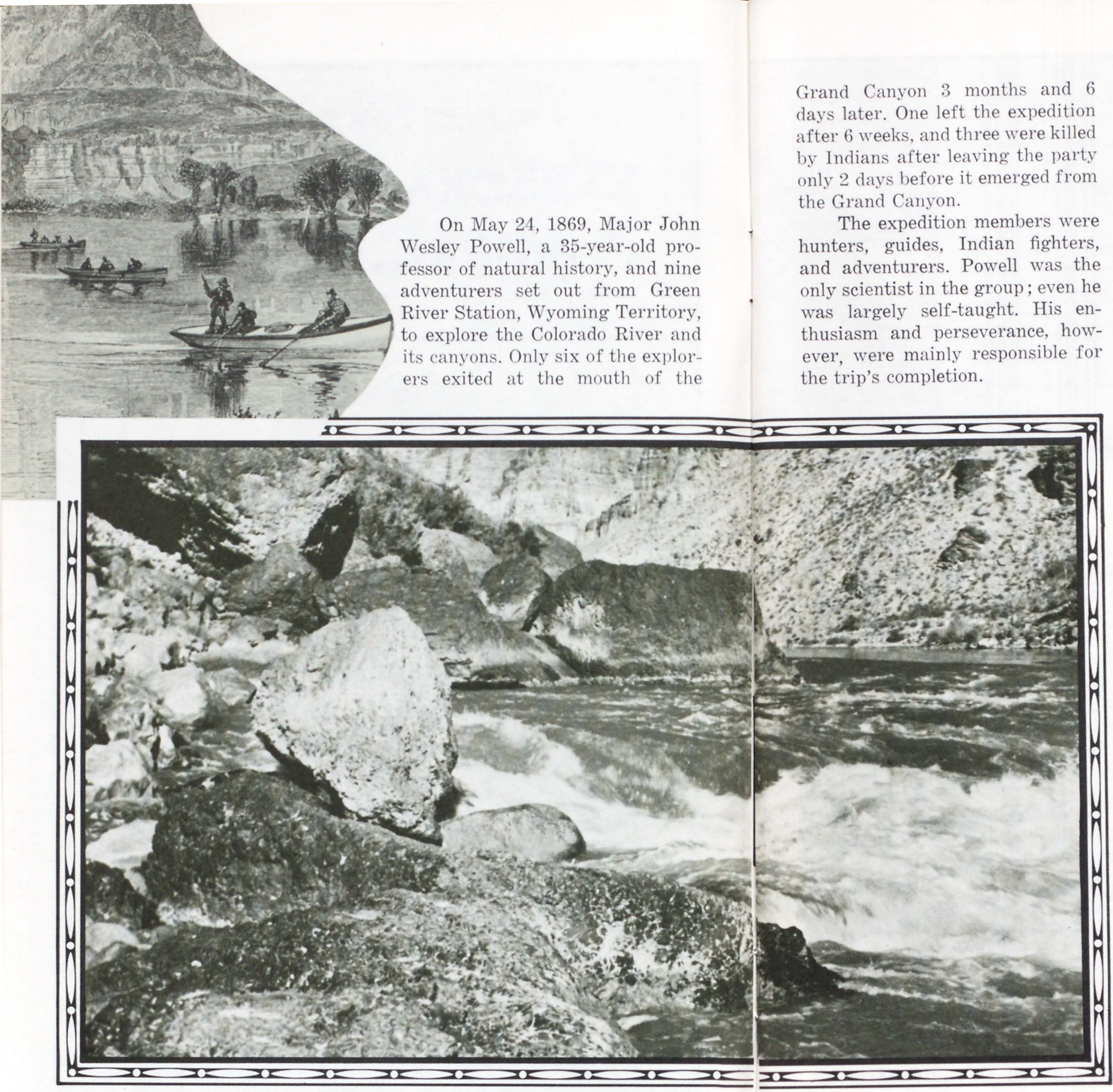

The area through which they traveled was then just a blank space on the map of the United States. Today much of the territory is unchanged from what it was when first penetrated by the Powell expedition.

From its headwaters on the west slope of the Rocky Mountains, the Colorado River follows a southwesterly course across the high Colorado Plateau and the low-lying Basin and Range province to the Gulf of California. Its course has been cut through mountains, plateaus, and desert plains; it is cliffbound nine-tenths of its way across the plateaus of southeastern Utah and northwestern Arizona.

Geologically, the part of the river explored by Powell is largely within the Colorado Plateau, an area of nearly horizontal sedimentary rock that stands at great altitude, generally more than 5,000 feet high, and is locally upwarped into mountains. The streams flow in steep-walled canyons, many of which are brilliantly colored. The climate is arid and vegetation is sparse. There are extensive areas of bare rock.

The largest, deepest, and most spectacular canyon through which the river flows is the Grand Canyon in northern Arizona, 217 miles long and from 14 to 18 miles wide. The south rim of the canyon is 7,000 feet above sea level and nearly 1 mile above the canyon floor. The north rim is 8,200 feet above sea 


TRIASSIC PERIOD

". the canyons of this region would be a Book of, Revelations in the rock-leaved
Bible of geology."

level and averages more than 1 mile above the canyon floor.

The Grand Canyon has been carved by the Colorado River and its tributary streams, which have carried downriver the rocks and soil supplied to them by the weathering and breaking up of the canyon walls, and at the same time, have cut their own channels deep into the solid rock. Some geologists believe that it is geologically young, not more than a few million years old; others contend that it has been carved out by the river over a much longer period, perhaps several tens of millions of years.

The river itself has cut only a narrow slot. The great width of the Grand Canyon is the result of erosion by landslides, runoff of water from the sides, ice and frost action, and other wearing agents.

In cutting the chasm, the Colorado River has exposed a great series of rock layers. Fine examples of the rocks of all known eras of geologic time (from the Precambrian to the Cenozoic) may be seen, recording a span of nearly 2 billion years. In these rock layers are fossil remnants of prehistoric life ranging from primitive sea plants to early kinds of land life such as ferns and lizardlike reptiles.

The earliest known settlers in the Colorado basin were a prehistoric people called Hohokan, who lived and vanished in the Salt River Valley before the Hopi and Pueblo Indians inhabited the area. The Papago Indians are probably their descendants. The ancestors of the Apache and Navajo Indians came in the 13 th century.

Probably the first European to see the Colorado River was Francisco de Ulloa, a Spanish soldier and explorer, who reached the head of the Gulf of California in his search for the famed Seven Cities peans to view the Grand Canyon were Captain Garcia Lopez de Cardenas and 12 soldiers, who in 1540 were sent by Francisco Vasquez de Coronado, Spanish explorer of the Southwest, to verify Indian tales of "a great river and chasm."

Father Eusebio Kino, a Jesuit priest, established missions in Arizona at San Xavier de Bac in 1700 and at Gueravi in 1732. The first European settlement was established near present-day Tucson, Arizona in 1776 .

Until Powell's exploration, little was known of the Grand Canyon, its surrounding plateaus, or the long reaches of river above it. Legends told of expeditions that had tried to pass through the canof Cibola in 1536. The first Euro-

yon only to perish in unknown rapids or on lonely rock shores. If any of these early expeditions did get through, they left no record behind. Even the official view of the United States Government was discouraging. Lieutenant Joseph C. Ives, who in 1857 was sent by the War Department to explore the river, traveled by steamer from the mouth of the river as far upstream as Black Canyon. In his report he said :

Ours has been the first, and will doubtless be the last party of whites to visit this profitless locality... It seems intended by nature that the Colorado, along the greater part of its lonely and majestic way, shall be forever unvisited and undisturbed.

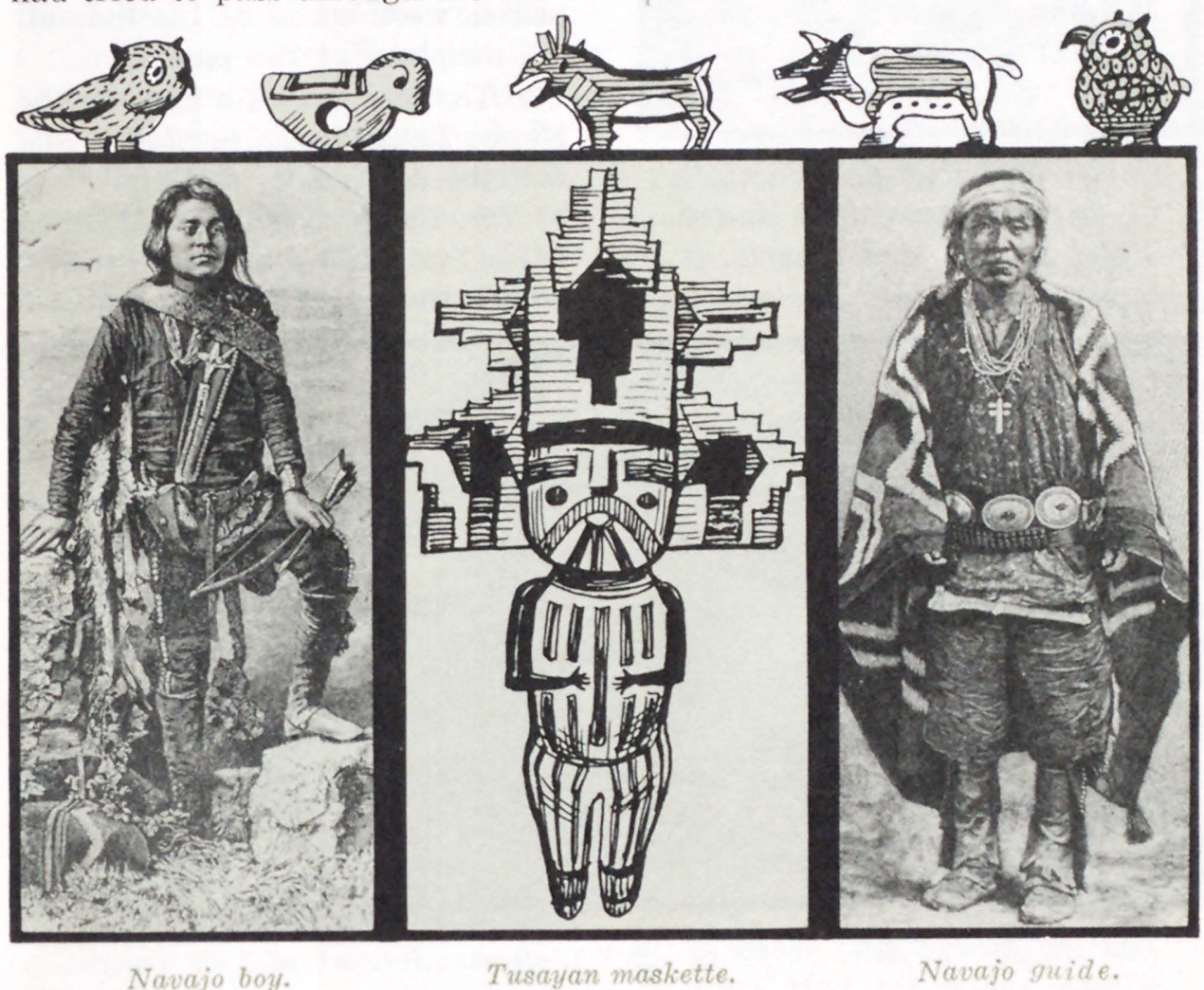


But neither legends, Indian warnings, nor the Ives report discouraged Powell. In his own report on the expedition, published in 1870, Powell wrote:

For two or three years I have been engaged in making some geographical studies in the mountains to the east and north of the Colorado Basin, and while pursuing them the thought grew into my mind that the canyons of this region would be a Book of Revelations in the rock-leaved Bible of geology. The thought fructified, and I determined to read the book; so I sought for all the available information with regard to the canyon land. I talked with Indians and hunters, I went among the Mormons to learn what they knew of this country adjacent to the "Kingdom of God," the home of the "Church of Jesus Christ of Latter-day Saints." I read the reports of the United States Survey, and I explored canyons of the tributary

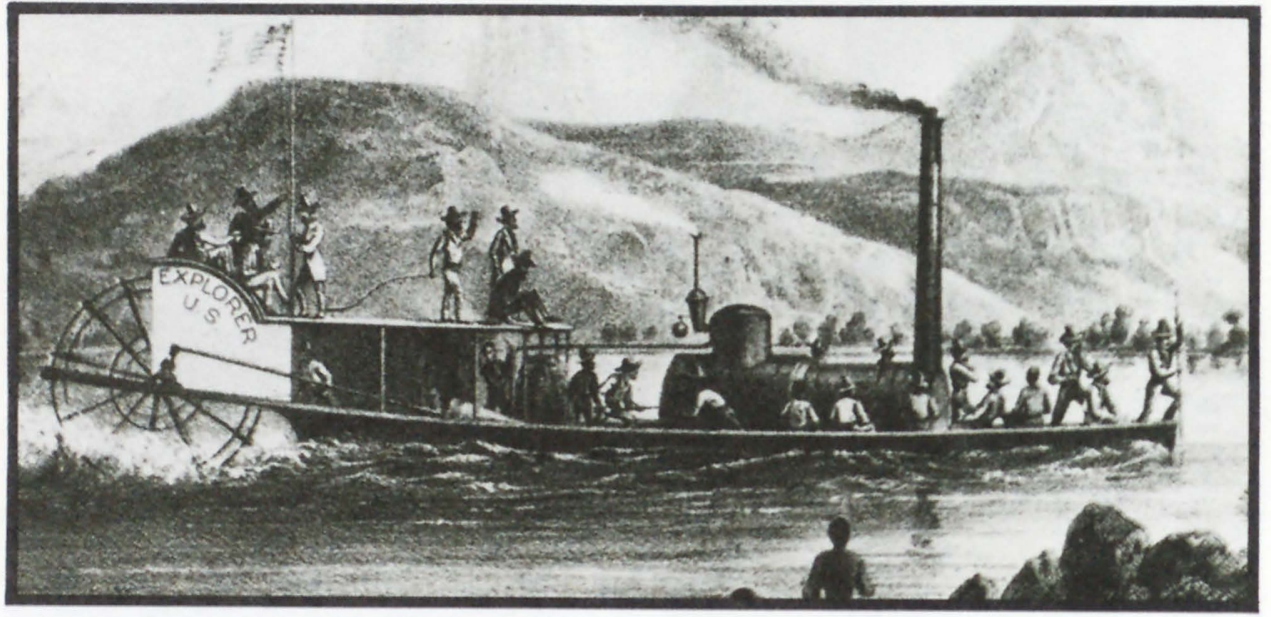

streams that I thought would represent somewhat the nature of the Grand Canyon, on account of similar geological and physical features. From the fabulous stories, the facts, and the reports, and from the knowledge of other canyons, I came to the belief that the "Grand Canyon of the Colorado" could be explored by descending the river in small boats.

By spring of 1869 , Powell was ready to start. The Illinois Natural History Society and Illinois Industrial University supplied funds. Congress authorized Powell to draw rations from Army posts for a party of 25 men and the Smithsonian Institution provided him with scientific instruments. Personal expenses were borne by the individual members of the party.

The four boats for the trip, the Emma Dean, the Kitty Clyde's Sister, the No Name, and the Maid of the Canyon, waited at Green River Station, Wyoming Territory, where the party was to embark.

ieutenant Ives ascended the Colorado
The boats had been built according to Powell's specifications. Three were made of oak, were 21 feet long, and were equipped with compartments for storing food, ammunition, tools, and scientific instruments. The fourth was of identical design but only 16 feet long and of white pine. Being lighter "with a sharp cutwater and every way built for fast rowing," it served as the lead boat.

Four men of the party had served as guides and assistants to Powell the year before: Jack Sumner, O. G. Howland, Bill Dunn, and Billy Hawkins. Sumner was a Civil War veteran who operated a small trading post in Middle Park, west of Denver. Abandoning the trading post, he joined Powell and enlisted the services of Howland, Dunn, and Hawkins. Howland was a printer and editor from Denver, and Hawkins was a Union Army veteran who was suspected by Powell's party of being a fugitive from justice. Little is known of Dunn. In addition, there were Seneca Howland, a Civil War veteran and brother of O. G. Howland; Captain Walter H. Powell, the Major's brother, who had been imprisoned during the war; G. Y. Bradley, a veteran of the Civil War and later a sergeant in the Regular Army,

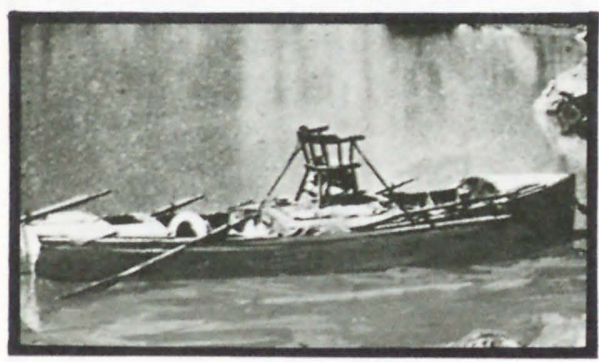

Major Powell's lead boat with his chair lashed to the dect.

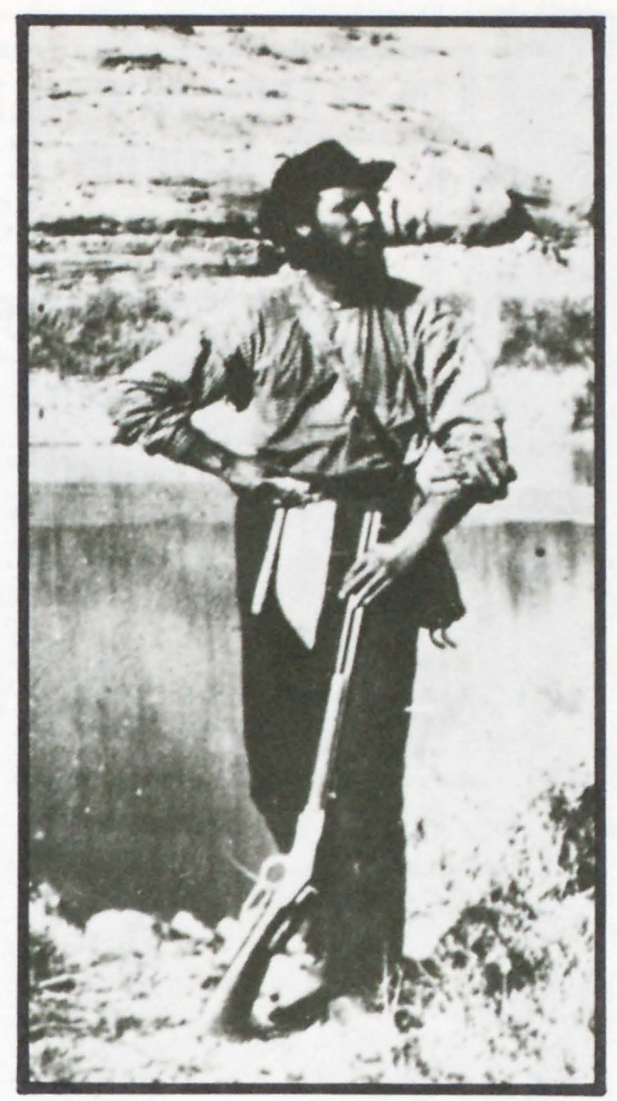

Typical equipment of a wiver explorergun, pick, mapcase, and canteen.

who had been discharged to accompany Powell on the trip; Frank Goodman, a young English adventurer; and Andy Hall, an 18-yearold mule driver and Indian scout.

By May 24, 1869, all plans had been completed, and the boats were moored along the shore. The men clambered aboard with Major Powell in the lead boat and-

. at half-past 1, we started from Green River City. The rations, instruments, etc. were so divided among the boats as to have a fair proportion of the several articles on each. This precaution was taken that we might not be 


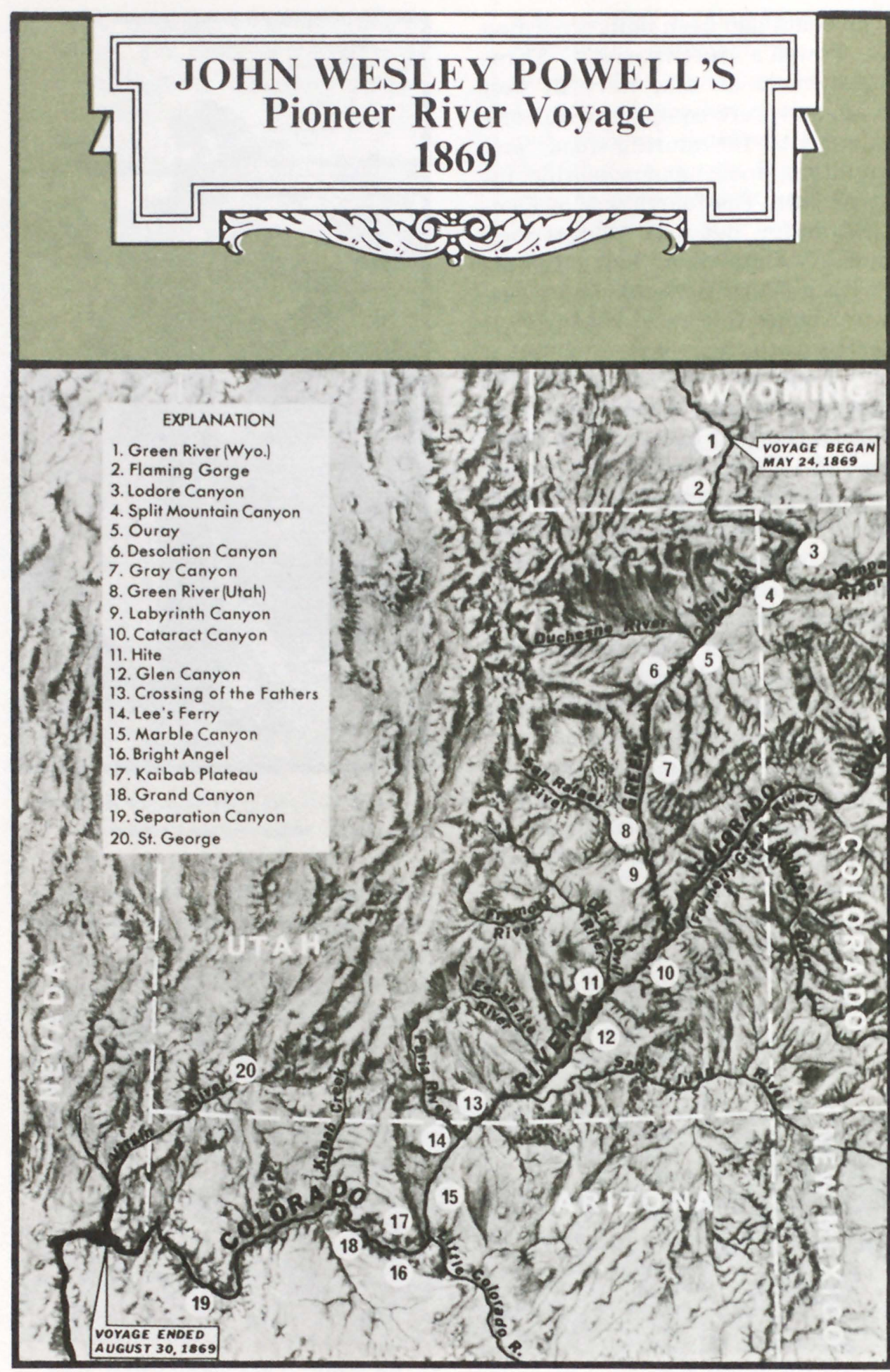

and gray at the summit of the cliffs, and curving down to the water's edge on the nearer slope of the mountain. This is where the river enters the mountain range - the head of the first canyon we are to explore, or, rather, an introductory canyon to a series made by the river through the range. We have named it "Flaming Gorge."

June 6 . . We left camp at Flaming Gorge on the 30th of May, and quickly ran through the gorge; then wheeled to the left on the swiftly gliding current into another canyon with a direct run of nearly a mile; then the river turned sharply, around the point of a narrow cliff to the right, about 

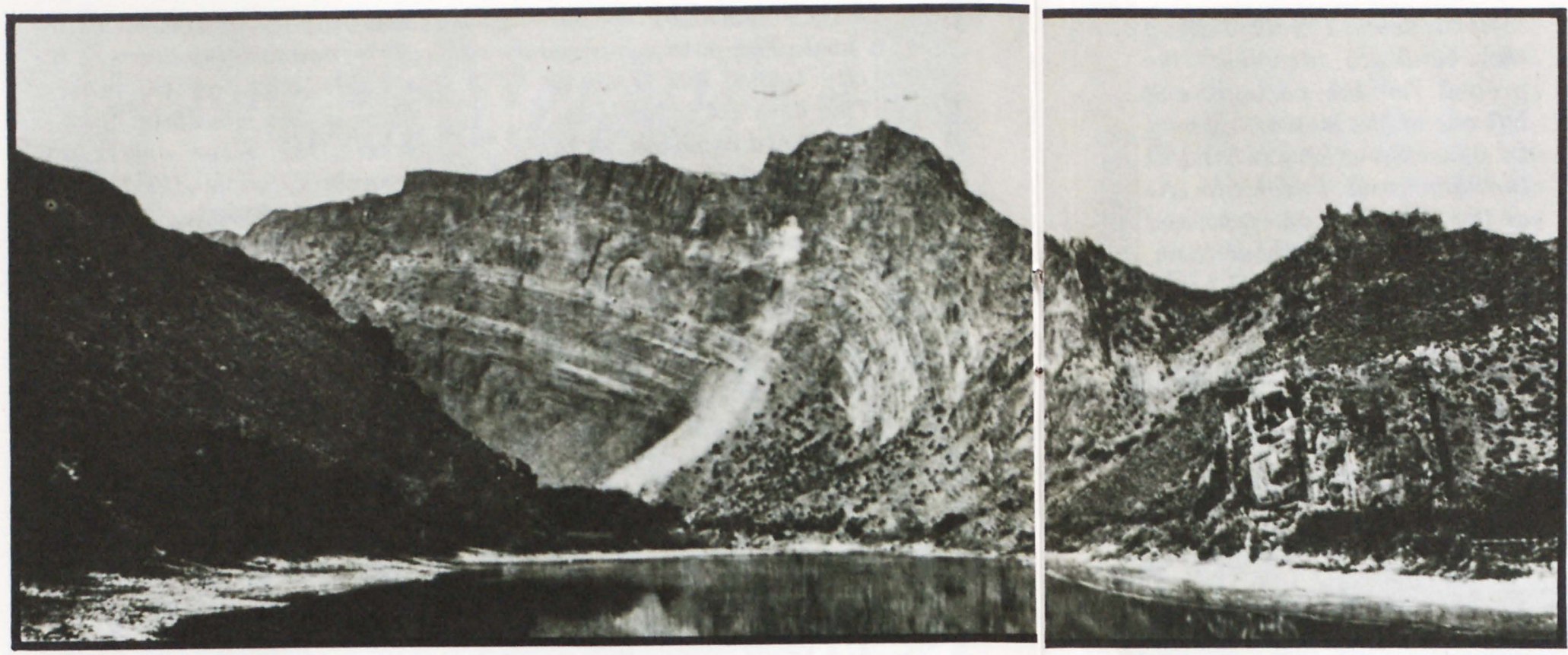

Entrance to Flaming Gorge, Green River, Utah, the first canyon explored by Powell's party.

1,500 feet high, and rolled in great waves back again to the west ford another mile; then became a quiet stream in a little valley. As this was our first experience with canyon rapids, we called it "Canyon of the Rapids." Soon we entered another canyon in the gray rocks, and made a ride to the point where the river makes its grand turn to the east, and camped for the night. This camp was on the south side of the river, just opposite a dome-shaped mountain, around which the Green makes its turn, and we called it "Beehive Point." Down the river the mountains were of red sandstone, and the evening sun played in roseate flashes from the rocks and shimmering green from the cedar spray along the dancing waves away down the river.

The course of the Green River through the Uinta Mountains furnished the basis for one of Powell's major contributions to geology: the theory of antecedent rivers. He believed that the Green River was older than the mountains, which slowly rose up athwart the river's course. The river excavated its bed as fast as the rocks were uplifted, just as a revolving saw cuts its way through a log held against it.

Without trouble beyond the normal rigors of the voyage, the party continued downstream. After passing through Red Canyon, they camped under a giant cottonwood standing on the river bank. The party rested for 3 days before attempting the next canyon, which later they named Lodore. and shimmered and flashed
Sitting high on a cliff overlooking the camp, Powell wrote:

While I write, I am sitting on the same rock where I sat last spring, with Mrs. Powell, lookWhen I came down at noon, the sun shone in splendor on its vermilion walls shaded into green and gray when the rocks are lichened over. The river fills the channel from wall to wall. The canyon opened like a beautiful portal to a region of glory. Now, as I write, the sun is going down and the shadows are setting in the canyon. The vermilion gleams and rosy hues, the green and gray tints are changing to sombre brown above, and black shadows below. Now'tis a black portal to a region of gloom. ing down into this canyon.
And that is the gateway through which we enter our voyage of exploration tomorrow-and what shall we find?

On the morning of June 8 the travelers entered Lodore Canyon. Aboard the lead boat, the Emma Dean, Powell described how they proceeded:

June 8-I must explain the plan running these places. The light boat, "Emma Dean," with two good oarsmen and myself explore them, then with flag I signal the boats to advance, and guide them by signals around dangerous rocks.

When we come to rapids filled with boulders, I sometimes find it necessary to walk along the shore for examination. If 'tis thought possible to mun, the light boat proceeds. If not, the

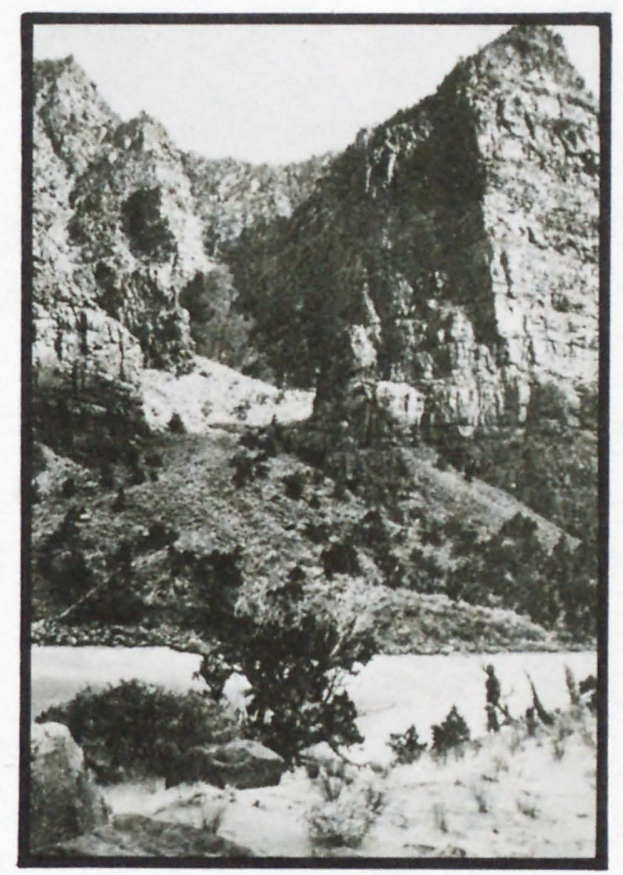

Lodore Canyon, Green River, Colorado. 
others are flagged to come on to the head of the dangerous place, and we let down with lines, or make a portage.

And then disaster-

At the foot of one of these runs, early in the afternoon I found a place where it would be necessary to make a portage, and signalling the boats to come down, I walked along the bank to examine the ground for the portage, and left one of the men of my boat to signal the others to land at the right point. I soon saw one of the boats land all right, and felt no more care about them. But five minutes after $I$ heard a shout, and looking around,

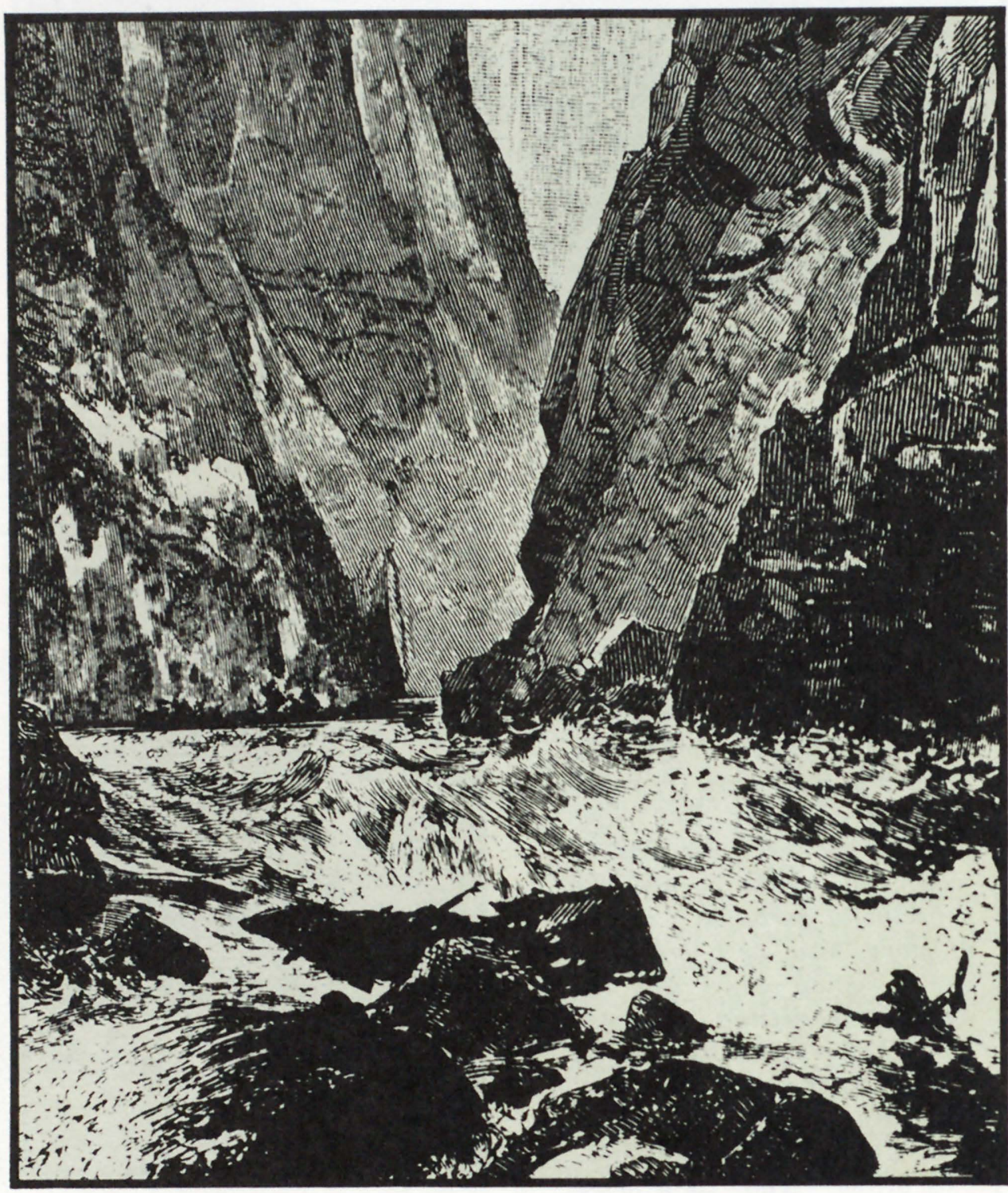

I saw one of the boats coming over the falls. Capt. Howland, of the "No Name," had not seen the signal in time, and the swift current had carried him to the brink. I saw that his going over was inevitable, and turned to save the third boat. In two minutes more I saw that turn the point and head to shore, and so I went after the boat going over the falls. The first fall was not great, only two or three feet, and we had often run such, but below it continued to tumble down 20 to 30 feet more, in a channel filled with dangerous rocks that broke the waves into whirlpools and beat them into foam. I turned just to see the boat strike a rock and throw the men and cargo out. Still they clung to her sides and clambered in again and saved part of the oars, but she was full of water, and they could not manage her. Still down the river they went, two or three hundred yards to another rocky rapid just as bad, and the boat struck again amidships, and was dashed to pieces. The men were thrown into the river and carried beyond my sight.

Although the three men were washed ashore uninjured, the $N_{0}$ Name was completely wrecked. Rations, instruments, and clothing were lost. Only two barometers and a keg of whiskey were recovered. With good reason the men later named this place "Disaster Falls."

Of the recovered whiskey, Powell later wrote, ". . . they had taken it on board unknown to me, and I am glad they did, for they think it does them good-as they are drenched every day by the melted

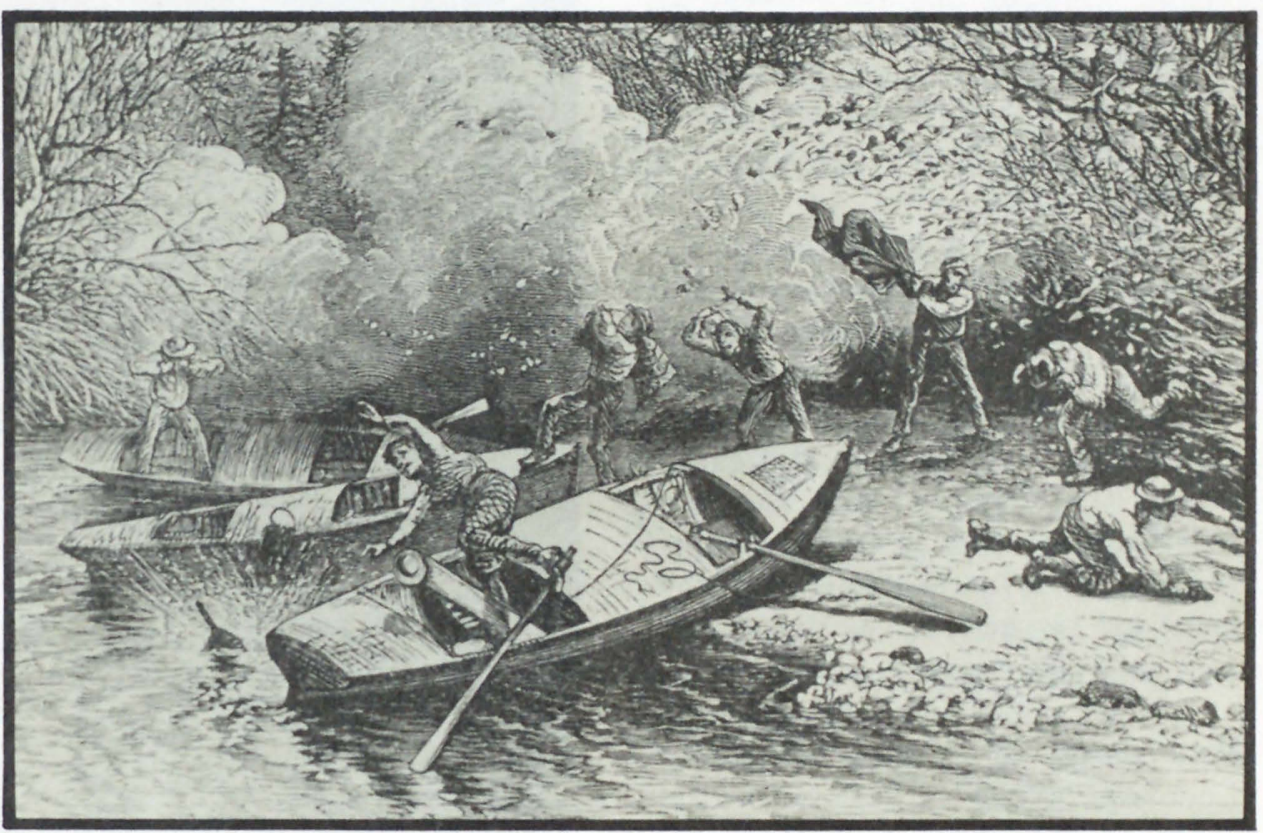


snow that runs down this river from the summit of the Rocky Mountains-and that is a positive good itself."

Bad luck continued to plague the explorers. Only a little more than a week later, they camped in a little alcove bordered by cedars on one side and a dense mass of box elders and dead willows on the other. Powell and Captain Howland went to explore the stream coming down into the alcove, and-

While I was away, a whirlwind came and scattered the fire among the dead willows and cedar spray, and soon there was a conflagration. The men rushed for boats, leaving all behind that they could not carry at first. Even then, they got their clothes burned and hair singed, and Bradley got his ears scorched. The cook filled his arms with the mess kit, and jumping onto the boat, stumbled and threw it overboard, and his load was lost. Our plates are gone, our spoons are gone, our knives and forks are gone; "Water ketch'em," "H-e-a-p ketch'em."

The men were compelled by the blaze to cut the boats loose, and the swift current quickly carried them down the river and over a rapids. All landed safely and made their way back to the camp where they found some clothing and bedding, also a few tin cups, basins, and a kettle. "This is all the mess kit we now have. Yet we do just as well as ever."

With great relief, on June 18, they emerged from the 21-mile-long Lodore Canyon.

$$
\text { We are out of Lodore }
$$

Canyon at last. Although its walls and cliffs, its peaks and crags, its amphitheaters and alcoves tell a story of beauty and grandeur, the roar of the waters was heard un ceasingly from the hour we entered it until we landed here. No quiet in all that time.

At the mouth of the Yampa River, they camped in a place they called Echo Park and soon ran into still another canyon.

W. . very narrow with high vertical walls. Here and there huge rocks jutted into the water from the walls, and the canyon made frequent and sharp curves. The waters of the Green are greatly increased since the Yampa came in, as that has more water than the Green above. All this vol ume of water, confined as it is in a narrow channel, is set ed dying and spinning by the projecting rocks and points, and curves into whirlpools, and the waters waltz their way through the canyon, making their own rippling, rushing, roaring music.

The boats were managed with difficulty, spinning as they did in eddies, and rearing and plunging with the waves. Before sunset, the party reached a quiet valley in which they camped, naming the place Island Park. After 2 days spent recalking the heavily leaking boats, they resumed their journey. More rapids were run in Split

\section{Repairing a boat in the first Granite Gorge of the Grand Canyon.}

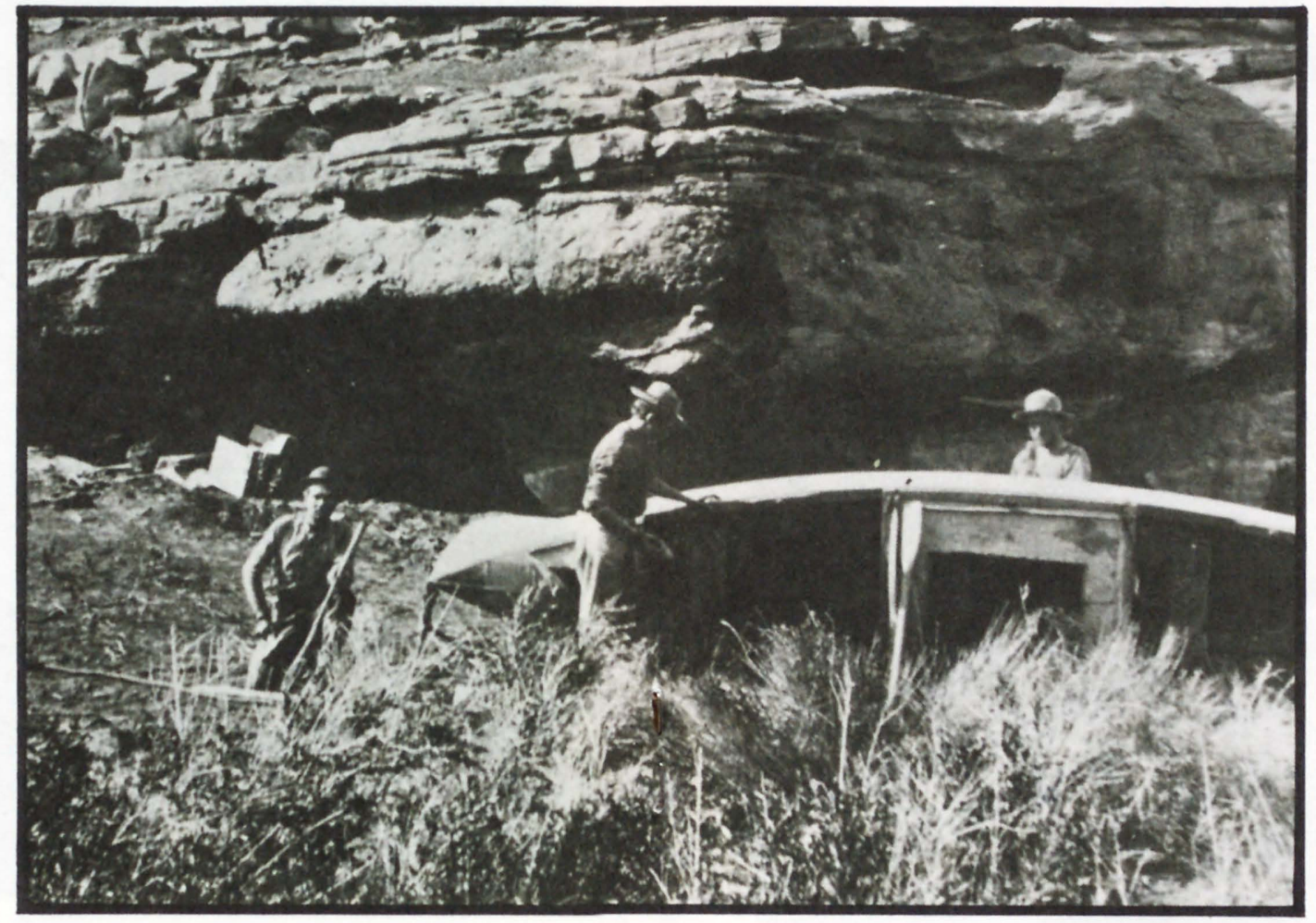

Mountain Canyon, which they entered on June 25. The next forenoon was spent in portaging and then more gliding on gently flowing water, until on June 28, as George Bradley recorded in his diary, they-

. reached the desired point at last and have camped close to the mouth of the Uin-

- ta River. The White River comes in about a mile below on the other side. Now for letters from home and friends, for we shall here have an opportunity to send and receive those that have been forwarded through John Heard.

Several of the party went to the Uinta Indian Agency; Captain Howland observed that-

This valley, as also the valleys of the White and Uinta for twenty-five or thirty miles, has the appearance of being very fine for agricultural purposes and for grazing. The Indians on Uinta Agency have fine looking crops of corn, wheat and potatoes, which they put in this spring, on the sod. They have also garden vegetables of all kinds, and are cultivating the red currant. Everything is said to look well. Most of the Indians are now from the agency to see the railroad, while the rest stay to attend to their stock and keep their cattle from getting in and eating up their crops.

Here, Frank Goodman left the party, feeling he had had sufficient adventure.

They left the mouth of the Uinta on July 6 and trouble continued to plague them. On July 


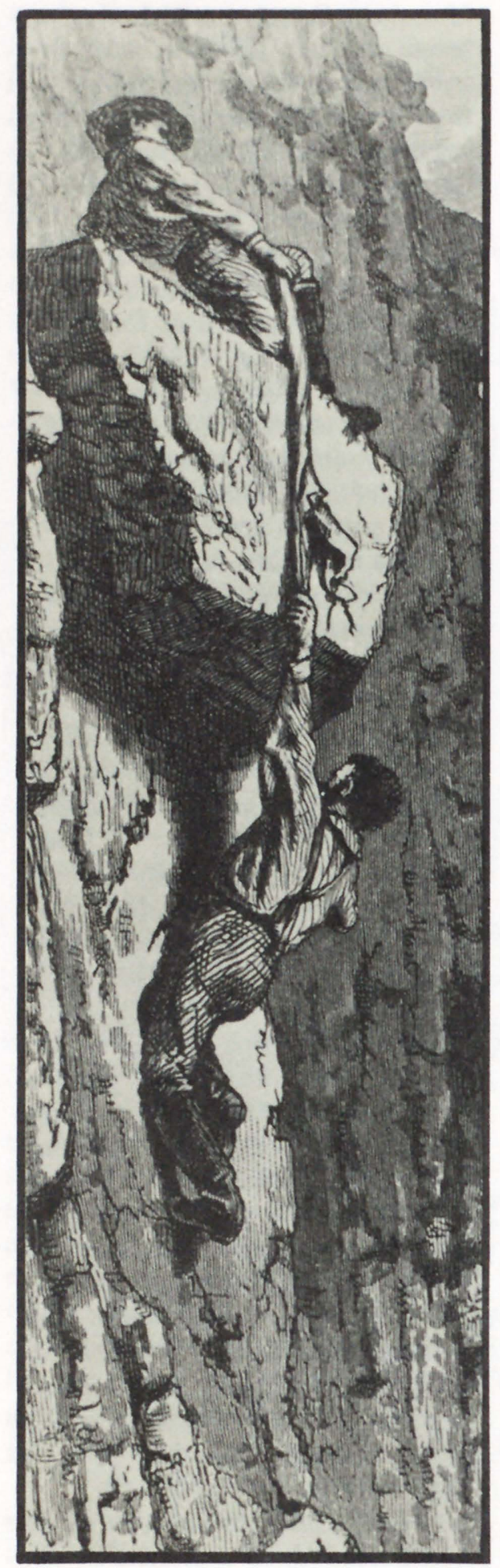

The resone
8, Powell almost lost his life. Through years of mountain climbing Powell had become used to heights. He could sit seemingly undisturbed on the edge of a 2,000 foot precipice. He often scrambled out of gorges to the rims of surrounding canyons, usually encumbered by bulky equipment. Most often he returned long after dark.

One day while he and Bradley were climbing a particularly precipitous cliff (Echo Rock), Powell reached a place where he could not go up or down, but could only cling to a crevice in the rocks with the fingers of his one hand. Powell later described his near disaster:

.. by making a spring, I gain a foothold in a little crevice, and grasp an angle of the rock overhead. I find I can get up no farther, and cannot step back, for I dare not let go with my hand, and cannot reach foothold below without. I call to Bradley for help. He finds a way by which he can get to the top of the rock over my head, but cannot reach me. Then he looks around for some stick or limb of a tree, but finds none. Then he suggests that he had better help me with the barometer case; but I fear I cannot hold on to it. The moment is critical. Standing on my toes, my muscles begin to tremble. It is sixty or eighty feet to the foot of the precipice. If I lose my hold I shall fall to the bottom, and then perhaps roll over the bench, and tumble still farther down the cliff. At this instant it occurs to Bradley to take off his drawers, which he does, and swings them down to me. I hug close to the rock, let go with my hand, seize the dangling legs, and, with his assistance, I am enabled to to gain the top.

The two men continued their climb to the top of the cliff to make their scientific observations, and returned to camp apparently unmoved by the near disaster.

They were now into a "region of wildest desolation."

... The canyon is very tor tuous, the river very rapid and many lateral canyons enter on either side. The walls are almost without vegetation; a few dwarf bushes are seen here and there clinging to the rocks, and cedars grow from the crevices-not like the cedars of a land refreshed with rains, great cones bedecked with spray, but ugly clumps, like war clubs beset with spines. We are minded to call this the Canyon of Desolation.

July 11-A short distance below last night's camp we run a rapid, and in doing so break an oar and then lose another, both belonging to the "Emma Dean." Now the pioneer boat has but two oars. We see nothing from which oars can be made, so we conclude to run on to some point where it seems possible to climb out to the forests on the plateau, and there we will procure suitable timber from which to make new ones. 
We approach another rapid and standing on deck, I think it can be run and on we go. We try to land at the foot of the rapids but crippled as we are by the loss of two oars, the bow of the boat is turned downstream. We shoot by a big rock; a wave rolls over our little boat and fills her. I see that the place is dangerous and quickly signal to the other boats to land where they can. Another wave rolls our boat over and I am thrown some distance into the water. I soon find that swimming is very easy and I cannot sink. It is only necessary to ply strokes sufficient to keep my head out of water, though now and then, when a breaker rolls over me, I close my mouth and am carried through it. The boat is drifting ahead of me 20 or 30 feet and when the great waves have passed I overtake her and find Sumner and Dunn clinging to her.

As soon as the three men reached quiet waters, they turned the boat over to learn that their blanket rolls, two guns, and a barometer were lost.

On July 15, they passed the mouth of the San Rafael River, which came down from the distant mountains in the west. Late in the afternoon of the $16 \mathrm{th}$, they reached the junction of the Green and Grand Rivers. George Bradley said they-

TH...had been running all day through higher walls, mostly vertical, but the river was smooth though in some places more rapid than for two days.
The canyon looked dark and threatening but at last without warning, no valley or even opening unusual, it broke the Grand with a calm strong tide very different from what it has been represented ... The river Colorado formed by the iunction of these two is as we can see it calm and wide and very much unlike the impossible unpassable succession of foaming and raging waterfalls and cataracts which have been attributed to it.

The following day they overhauled their rations and found the flour in bad condition. After sifting it all through mosquito netting

$$
\text { Arriving at a campsite. }
$$

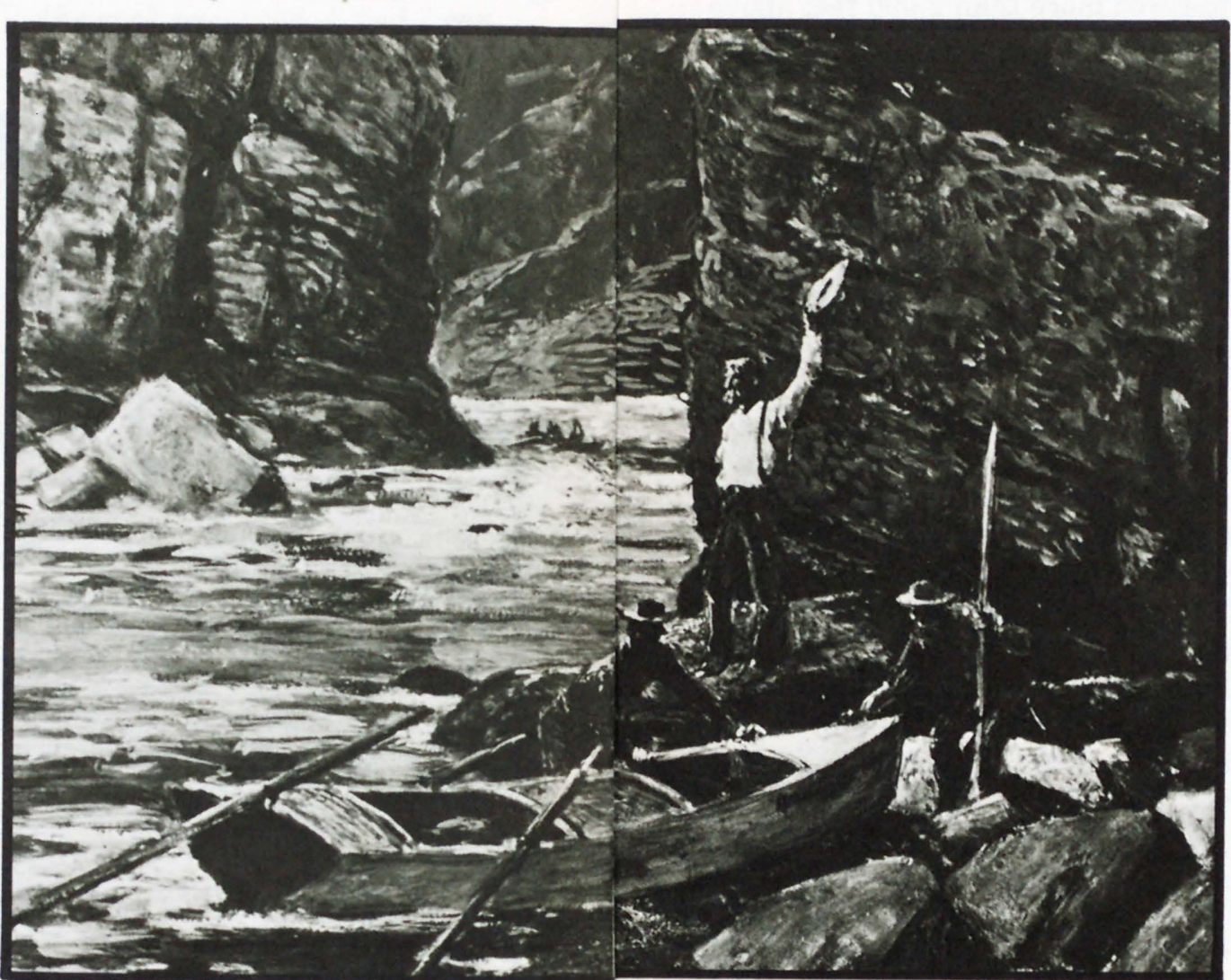

to take out the lumps, they had only about 600 pounds left.

July 18-The day is spent in obtaining the time and spreading our rations, which we find are badly injured. The flour has been wet and dried so many full of hard lumps. We make a sieve of mosquito netting and run our flour through it, losing more than 200 pounds by the process. Our losses, by the wrecking of the "No Name" and by various mishaps since, together with the amount thrown away today, leave us little more than two months' supplies, and to make times that it is all musty and them last thus long we must be fortunate to lose no more.

On the morning of July 21, the party started down the Colorado River.

The river is rough and bad rapids in close succession are found. Two very hard portages are made during the forenoon. After dinner, in running a rapid, the "Emma Dean" is swamped and we are thrown into the river; we cling to the boat, and in the first quiet water below she is righted and bailed out; but three oars are lost in this mishap. The larger boats land above the dangerous place, and we make a portage, which occupies all afternoon. We camp at night on the rocks on the left bank, and can scarcely find room to lie down. July 23-On starting, we come at once to difficult rapids and falls, that in many places are more abrupt than in any of the canyons through which we have passed. . . Early in the afternoon we arrive at the head of more rapids and falls, but wearied with past work, we determine to rest, so go into camp.

The men discussed the probabilities of successfully navigating the river below and concluded that:

there are great descents yet to be made, but if they are distributed in rapids and short falls as they have been before, we shall be able to overcome them; but maybe we shall come to a fall in these canyons which we cannot pass, where the walls rise from the water's edge, so that we cannot land 


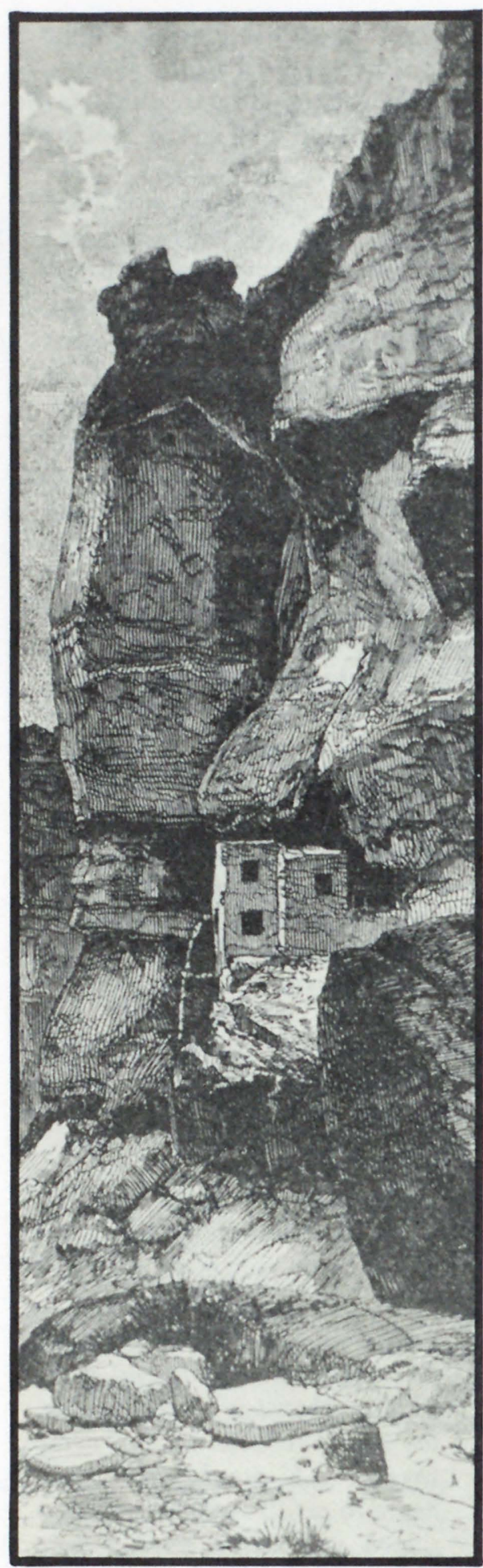

Ancient cliff house. and where the water is so swift that we cannot return. Such places have been found except that the falls were not so great but that we could run them with safety. How will it be in the future?

Trying to keep the boats in single file, they rowed on, cautiously feeling the way. Their voices were drowned by the sound of the river as the water broke over 50foot-high blocks of limestone. The boats became almost unsteerable as they shot down rapids and fell precariously over falls. Sometimes, caught in whirlpools, the boats spun endlessly.

As they continued, the river became even more swift and winding; the canyon walls narrowed and towered more than 2,000 feet above them, casting dark shadows over the water course. The men made their way with extreme care, hugging the left wall of the canyon and examining the gorge before them. It was with great relief that they finally emerged into open and quiet waters after traveling 41 miles through what was later called Cataract Canyon.

On July 28, they entered a long, straight canyon (later called Narrow Canyon) where the stream ran between low red cliffs. After a short distance, they came upon the mouth of a stream, entering from the right, that was not shown on any of their maps. As the water was muddy and had an unpleasant odor, they immediately named it the Dirty Devil River. On the left wall, opposite the mouth of the river, they discovered the ruins of an old building. After examining the cliffs, they climbed up to the eroded walls of the building and found arrowheads, broken pottery, and primitive etchings on the face of the cliff. Farther down the river, the party discovered a similar group of buildings; Powell surmised that Indians living in the area had fled to these cliffs and canyons for safety when attacked by nomadic tribes.

The explorers reached the mouth of the San Juan River on July 31, and on August 3 they arrived at "El Vado de los Padres" (the Crossing of the Fathers). It was here that the Fathers Garces (credited with naming the river the "Colorado") and Escalante, Spanish priests and explorers of the West, crossed the river in 1776 .

The journey continued through a canyon where the river, in its meanderings, had undermined the vertical walls. There were mazes of side canyons and gorges and huge potholes in the rocks. On the canyon walls and back many miles into the country, the explorers saw monument-shaped buttes, carved walls, royal arches, glens, alcoves, gulches, and mounds. They named it Monument Canyon, though later the name was changed to Glen Canyon.

The walls of the canyon they entered on August 5 were the limestone and hard sandstones they had earned to fear in Cataract Canyon. They traveled cautiously in water that boiled between sharp rocks and over limestone ledges. As they proceeded, the canyon walls rose higher and higher. In places, the river occupied the entire channel; the cliffs rose vertically from the water's edge and there was no place to land. The walls were of colored marble-white, gray, pink and purple.

* August 9 . . . Scenery on * grand scale. Marble walls polivished by the waves. Walls * 2,500 feet high. 3 portages before dinner. This afternoon $I$ had a walk of a mile on a marule ble pavement, polished smooth in many places, in others embossed in a thousand fantastic patterns. Highly colored mar* ble. Sun shining through cleft y in the wall and the marble 4 sending back the light in iridescence. At noon a cleft of canyon on left, quite narrow with a succession of pools one above another, going back and con$\checkmark$ nected by a little stream of I clear water. Pot holes filled with clear water. Banded marble at noon, $20 \mathrm{ft}$. out of the

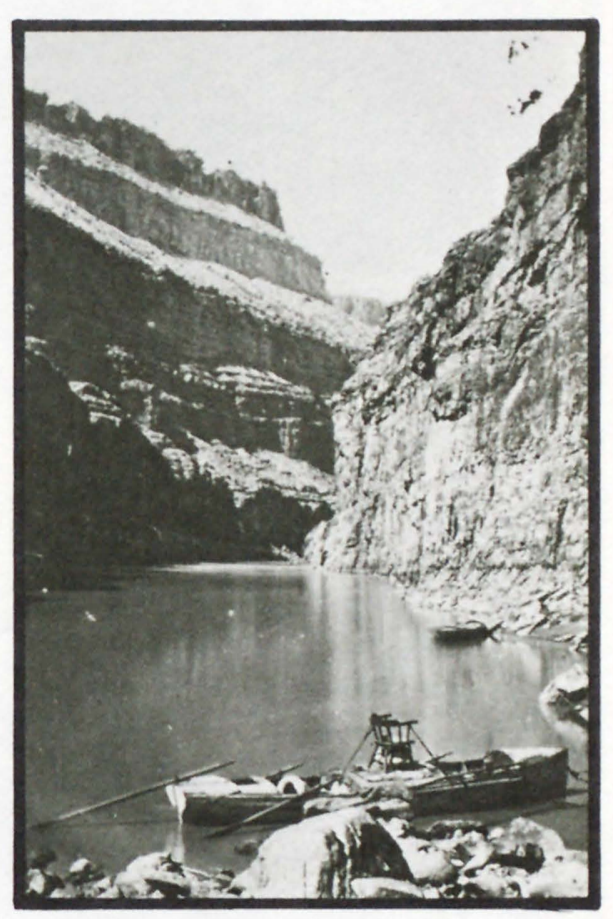

Marble Canyon. 
water. After dinner we found a spring gushing from an orifice in the marble, as silvery foam glad to see the light released from prison. A bank of brilliant verdure (ferns chiefly) on the talus below.

On August 10, after 71 days on the river, they reached the mouth of the Colorado Chiquito (Little Colorado), where they remained for 3 days determining the latitude and longitude, measuring the height of the walls, drying out their rations, and repairing their boats. Their food was reduced to flour, coffee, some bacon, and dried apples; half of their blankets were lost; their clothes were in rags. Powell described the experience in these words:

We are three-quarters of a 8. mile in the depths of the earth $\rightarrow$ and the great river shrinks into insignificance, as it dashes its angry waves against the The Colorado River at the head of the longest single drop.

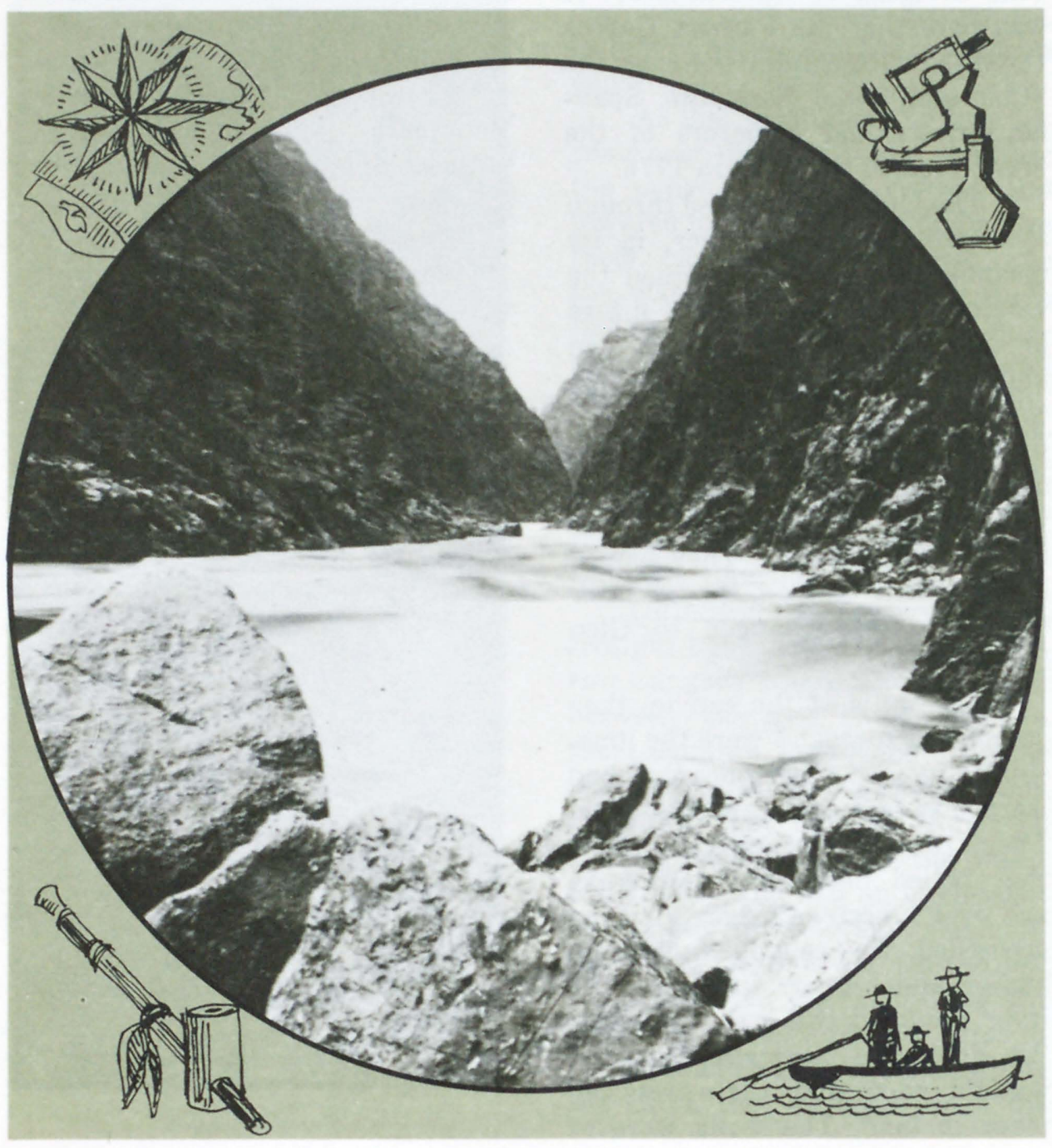

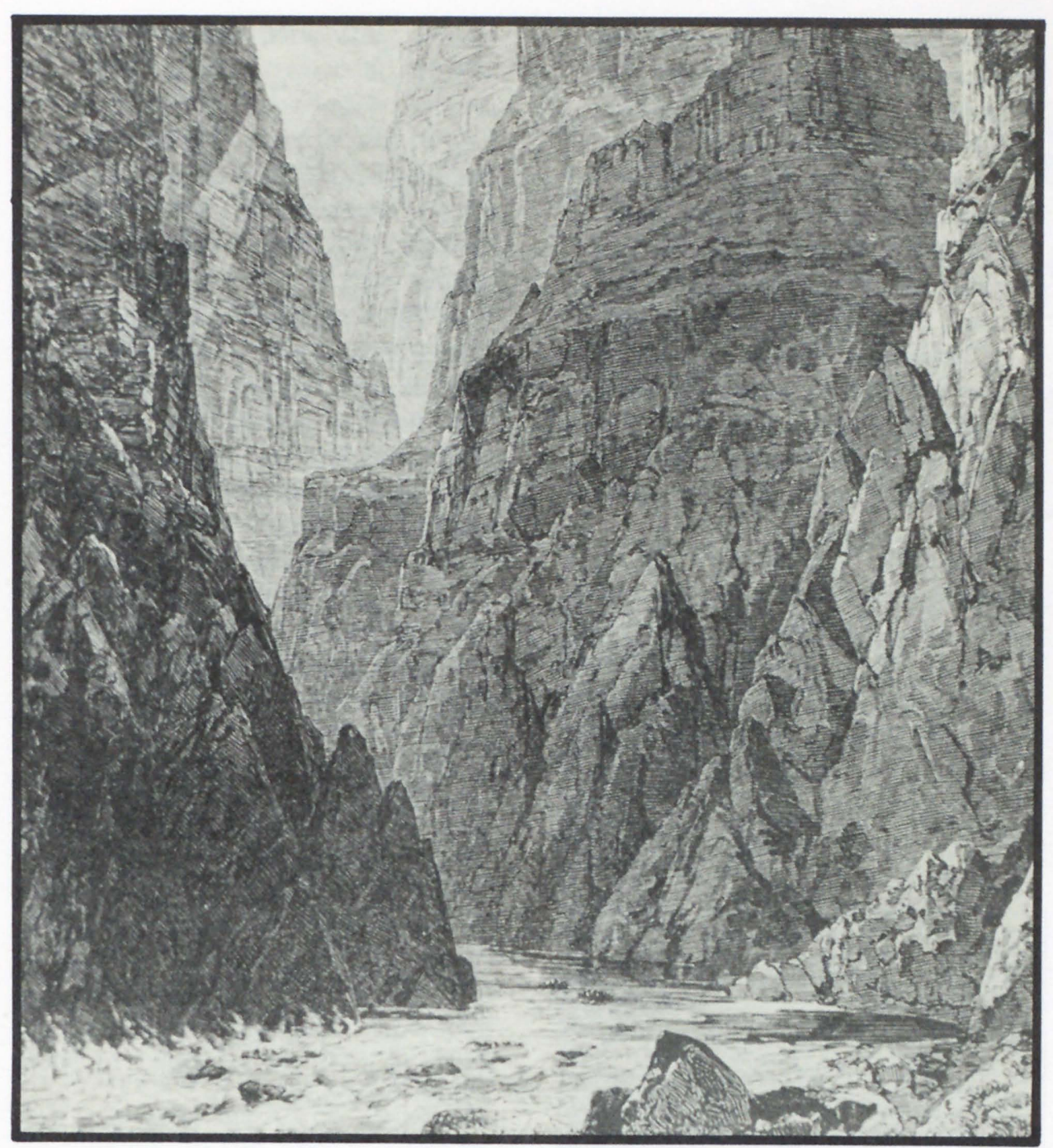

The Grand Canyon.

walls and cliffs, that rise to the world above; they are but puny ripples, and we but pigmies, running up and down the sands, or lost among the boulders.

We have an unknown distance yet to run, an unknown river yet to explore. What falls there are, we know not; what rocks beset the channels, we know not; what walls rise over the river, we know not.

August 13-We are now ready to start on our way down the Great Unknown. Our boats, tied to a common stake, chafe each other as they are tossed by the fretful river. They ride high and buoyant, for their loads are lighter than we could desire. We have but a month's rations remaining. The flour has been resifted through the 
mosquito-net sieve; the spoiled bacon has been dried and the worst of it boiled; the few pounds of dried apples have been spread in the sun and reshrunken to their normal bulk. The sugar has all melted and gone on its way down the river. But we have a large sach of coffee. The lightening of the boats has this advantage; they will ride the waves better and we shall have but little to carry when we make a portage.

Leaving the mouth of the Little Colorado, they made good progress through the swift water. The second day, August 14, the river entered a granite gorge narrower than they had yet seen. They became aware of a great roar and moved forward cautiously. The sound grew increasingly loud, and they found themselves above a long

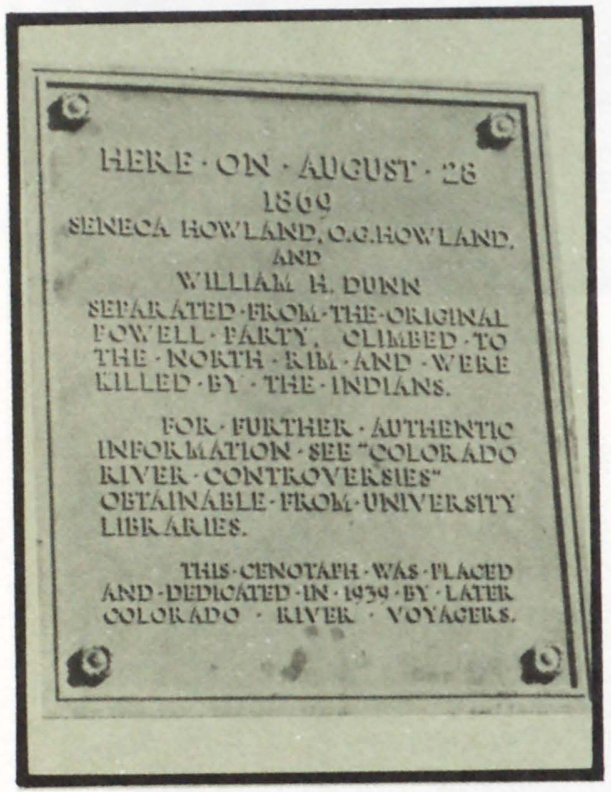

Plaque on the eastern side of Separation Canyon, marking the place where the Howland brothers and William H. Dunn left the 1869 Powell expedition. broken fall with ledges and pinnacles of rock jutting into the stream, their tops sometimes just below the surface. There was a descent of 75-80 feet in one-third of a mile, and the rushing waters broke into great waves on the rocks.

The walls were now more than a mile high. The gorge was black and narrow below, red and gray and flaring above, cut in many places by side canyons out of which streams flowed, adding to the turmoil of the river. Carried swiftly along, they listened for the roar of water that meant increased danger. The narrow canyon was winding and the river was closed in so that they could see but a few hundred yards ahead.

After making a difficult portage in the afternoon, the party finally landed the boats in a side canyon and climbed to a shelf 40 50 feet above the water where they camped for the night. It was raining, there was no shelter, and the men spent the night on the rocks, sleeping fitfully, wrapped in their rotted ponchos.

On August 16, they camped, remaining for a few days on a sandy beach above the mouth of a clear, glistening creek that Powell later called "Bright Angel." Here they whittled new oars from driftwood, recalked the boats, and dried out their rations once again. The bacon was badly spoiled and had to be thrown away. Their store of baking soda had been lost overboard, so they could have only unleavened bread to eat.

Ten days later, while still in the canyon, they came again to the dreaded granite. At noon on $\mathrm{Au}$ - gust 27, they approached a place in the river that seemed to be particularly threatening. Boulders that had been washed into the river formed a dam over which the water fell 18-20 feet. Below the boulder dam was a 300 -foot-long rock-filled rapids. On the side of the gorge, rock points projected from the wall almost halfway across the river. They tried in vain to find a way around it but finally concluded that they had to run it. There were provisions for only 5 days more.

Some of the men thought they should abandon the river. Captain Howland, his brother Seneca, and William Dunn decided to leave the party and go overland to the Mormon settlements about 75 miles to the north.

For the last 2 days the course had not been plotted, and Powell now used dead reckoning to determine their way. He found that they were only about 45 miles from the mouth of the Virgin River in a direct line, but probably 80-90 miles from it by the meandering line of the river. If they could navigate the remaining stretch of unknown water to that point, he reasoned, the journey up the Virgin River to Mormon settlements would be a relatively easy one.

Powell spent the night pacing up and down on the few yards of a sandy beach along the river. Was it wise to go on? While he felt that they could get over the immediate danger, he could not foresee what might be below. He almost decided to leave the river, but wrote, however:

For years I have been contemplating this trip. To leave the exploration unfinished, to say that there is a part of the canyon which I cannot explore, having already nearly accomplished it, is more than I am willing to acknowledge and I determine to go on.

August 28-At last daylight comes, we have breakfast, without a word being said about the future. The meal is as solemn as a funeral. After breakfast $I$ ask the three men if they still think it best to leave us. The elder Howland

Climbing the Grand Canyon wall.

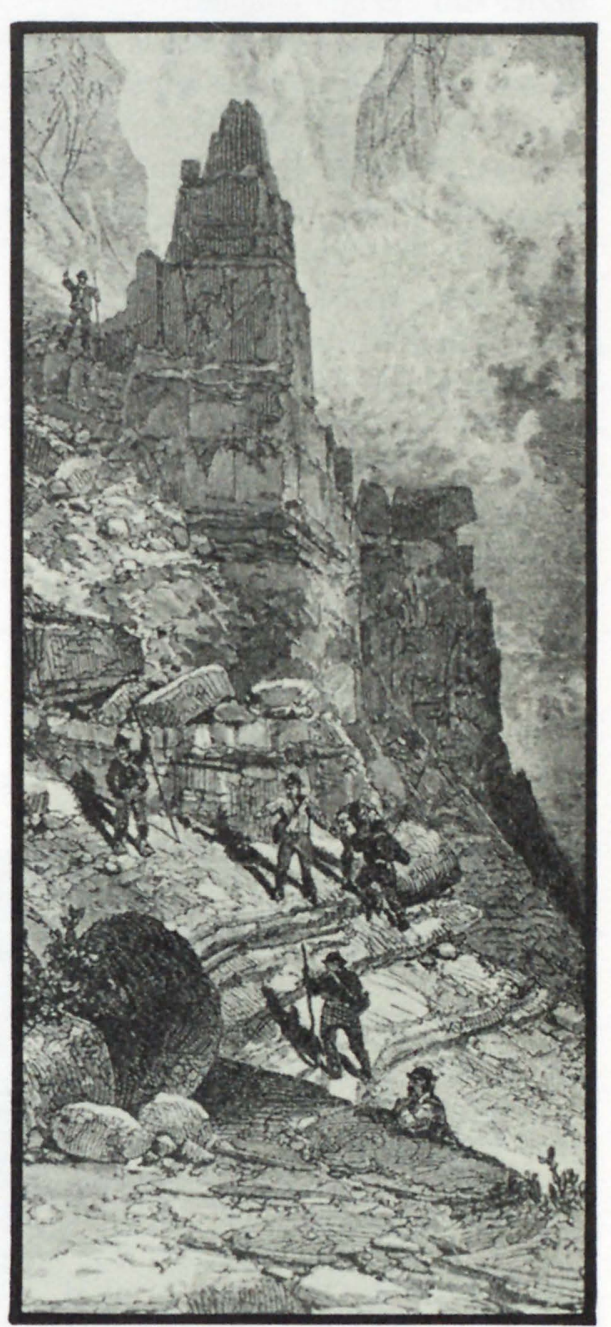


thinks it is, and Dunn agrees with him. The younger Howland tries to persuade them to go with the party, failing in which, he decides to go on with his brother.

Before they parted, Powell wrote a letter to his wife and gave it to Howland together with one copy of the records of the trip. Sumner gave Howland his watch asking him to send it to his sister should he not be heard from again. It was a solemn parting; each thought the other was taking the more dangerous course.

They divided the scanty $\mathrm{ra}$ tions and the guns and ammunition. The small boat was abandoned. First three men in one boat ran the rapids, then three in the other.

We are scarcely a minute in I running it, and find that, although it looked bad from above, we have passed many places that were worse... We land at the first practicable point below and fire our E guns, as a signal to the men above that we have come over

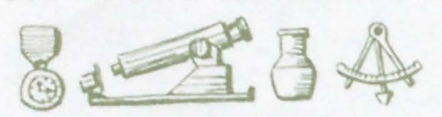

Ploque on the monument erected by Congress to commemorate the Powell
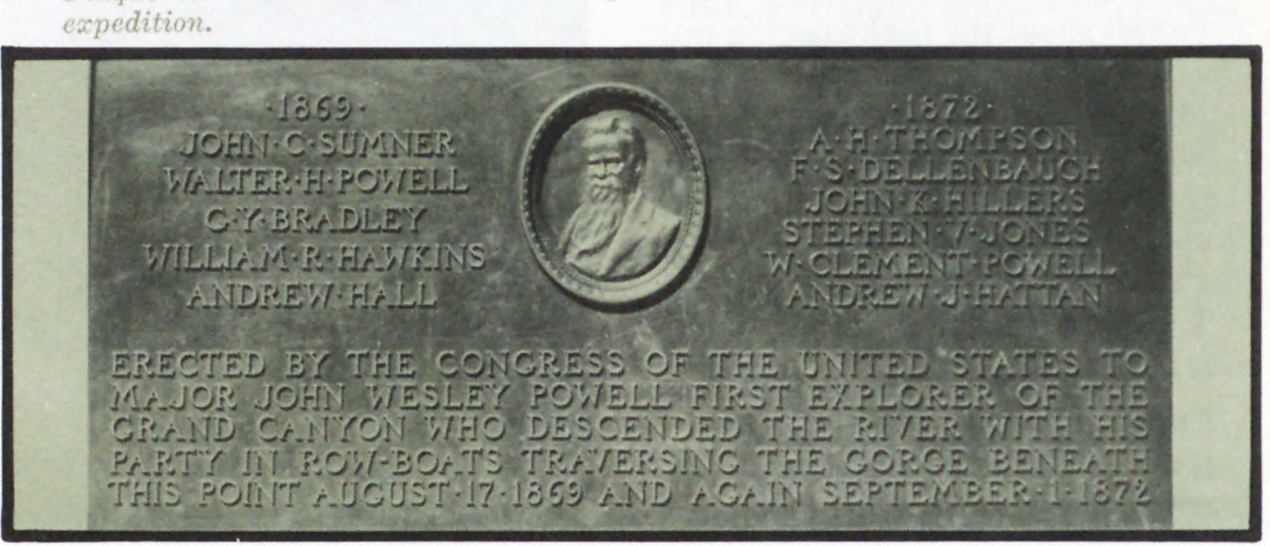
them, and so we wait until the country began to open up. On intention was to go on to Fort
Although Powell returned a couple of hours, hoping that 4 they will take the smaller boat and follow us. We are behind I a curve in the canyon, and cannot see up to where we left their coming seems hopeless,

4 and push on.

Later Powell learned that the three men had been killed by Shivwits tribesmen who, not believing the story of their coming down the canyon by way of the river, mistook them for miners who had molested a squaw.

Early on the morning of the 29th, the expedition again started downriver. At about 10 o'clock the 30th, they came, somewhat unexpectedly, to the mouth of the Virgin River. On September 1, Sumner, Bradley, Hawkins, and Hall took a small supply of rations and continued downstream. Their Mojave and then overland to Los Angeles. Major Powell and his brother left for Salt Lake City and then home. national hero, he was not satisfied with the results of his exploration. Notes had been lost; the few specimens collected had been cached. The scientific instruments had been badly damaged and the information obtained was not as complete or reliable as Powell wished.

Consequently, he planned another expedition to supplement the work of the first. By spring 1871 , everything was ready for Powell's second exploration of the Colorado River, its tributaries, and its canyons. Congress had appropriated funds, the members of the party had been selected, and three boats of improved design were waiting at Green River Station, Wyoming Territory.

On May 22, 1871, the party pushed their boats out into the stream-.

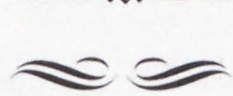

About the illustrations used in this publication.

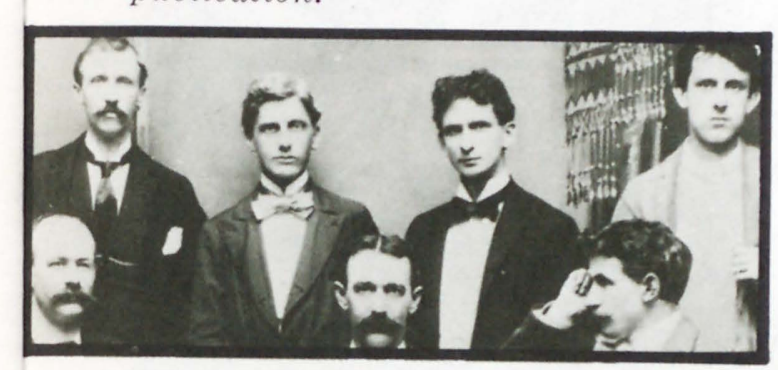

A group of illustrators from the Smithsonian Institution, 1876.

Many of the photographs and drawings used in this publication were produced as a result of Powell's second expedition. Although the first trip is more widely known, the second was far more productive in terms of documen- tation and scientific results. In Powell's Exploration of the Colorado (1875), ostensibly only the first trip was described in diary form, but some incidents and certainly a great amount of the descriptive information included were derived from the second trip. However, the diaries of George Bradley, Jack Sumner, and Major Powell, together with letters, provide ample information on the first trip.

One reason for the excellence of the documentation produced by the second expedition was the availability of a photographer. The crew that accompanied Powell on the second trip included an experienced photographer, E. O. Beaman. During the expedition's winter encampment of 1871-72, Beaman decided to leave the Powell party and return east. A new photographer, James Fennemore, was recruited in Salt Lake City, Utah, but stayed with the party only about 2 months.

After Fennemore left, the photographic work was assumed by John K. Hillers, a general handyman and boatman whom Powell had hired in Salt Lake City before starting on the expedition. Hillers had assisted Fennemore in his work and had quickly acquired a sufficient knowledge of photography to take over the job. He turned out to be a superb photographer and eventually became Chief Photographer of the newly formed U.S. Geological Survey. Most of the vast number of photographs produced by the second expedition were the work of Hillers.

The pictures acquired on the second trip were used as the basis for illustrations in Powell's later reports. Since halftone printing 
(offset) was not in general use at that time, artists were employed to convert the photographs into line drawings for use in the printed reports. Some liberties were taken by the artists in preparing the drawings. The cameras used by the explorers required a long exposure that made it impossible for them to record the turbulent water of the rapids, for instance. The artists, of course, corrected this and basically portrayed the scenes and activities as they were seen by the men of the expedition. Further retouching of the photographs has been performed on selected illustrations in this publication to improve the quality without impairing the pictorial content of the photographs.
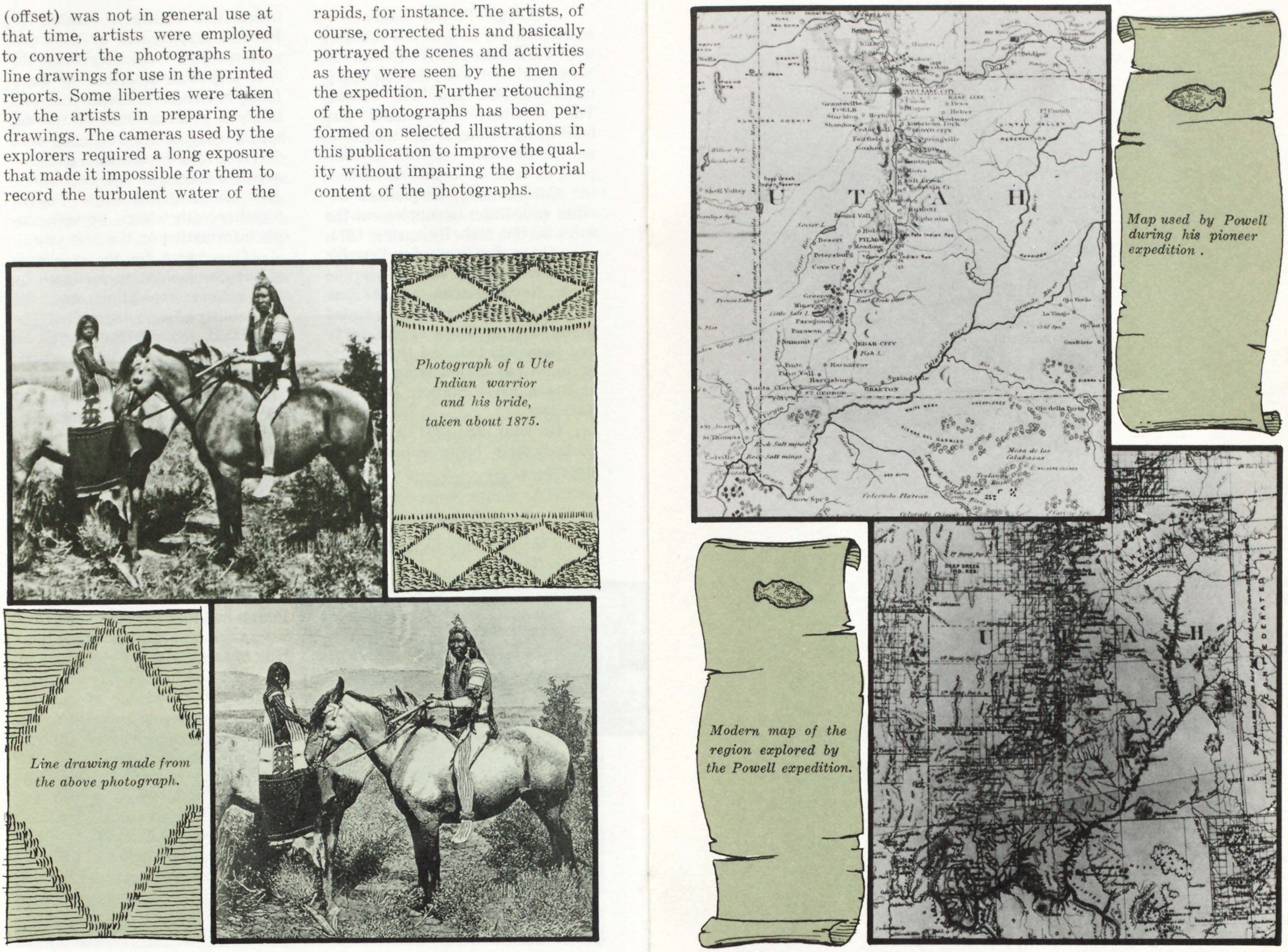
As the Nation's principal conservation agency, the Department of the Interior has responsibility for most of our nationally owned public lands and natural resources. This includes fostering the wisest use of our land and water resources, protecting our fish and wildlife, preserving the environmental and cultural values of our national parks and historical places, and providing for the enjoyment of life through outdoor recreation. The Department assesses our energy and mineral resources and works to assure that their development is in the best interests of all our people. The Department also has a major responsibility for American Indian reservation communities and for people who live in Island Territories under U.S. administration.
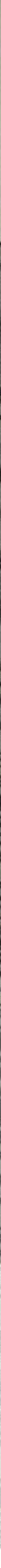